\title{
Selected Metals in Various Fractions of Soil and Fungi in a Swedish Forest
}

\author{
Mykhailo Vinichuk ${ }^{1,2}$ \\ ${ }^{1}$ Department of Soil and Environment, Swedish University of Agricultural Sciences, P.O. Box 7014, 75007 Uppsala, Sweden \\ ${ }^{2}$ Department of Ecology, Zhytomyr State Technological University, 103 Cherniakhovsky Street, 10005 Zhytomyr, Ukraine
}

Correspondence should be addressed to Mykhailo Vinichuk, mykhailo.vinichuk@slu.se

Received 14 April 2012; Accepted 11 May 2012

Academic Editors: S. Loppi and P. Rautio

Copyright (C) 2012 Mykhailo Vinichuk. This is an open access article distributed under the Creative Commons Attribution License, which permits unrestricted use, distribution, and reproduction in any medium, provided the original work is properly cited.

\begin{abstract}
The patterns of uptake and distribution of $\mathrm{Co}, \mathrm{Ni}, \mathrm{Cu}, \mathrm{Zn}, \mathrm{Cd}$, and $\mathrm{Pb}$ in the soil-mycelium-sporocarps compartments in various transfer steps are presented. I attempted to find out whether there is a difference between the uptake of metals from soil to fungi (mycelium/soil ratio) and transport within fungal thalli (sporocarps/mycelium ratio). The concentration of $\mathrm{Cu}, \mathrm{Zn}$, and $\mathrm{Cd}$ increased in the order bulk soil < soil-root interface (or rhizosphere) $<$ fungal mycelium $<$ fungal sporocarps. The concentration of $\mathrm{Co}, \mathrm{Ni}$, and $\mathrm{Pb}$ decreased in the order bulk soil (or rhizosphere) $<$ fungal mycelium $<$ soil-root interface $<$ fungal sporocarps. The uptake of $\mathrm{Cu}, \mathrm{Zn}$, and $\mathrm{Cd}$ during the entire transfer process in natural conditions between soil and sporocarps occurred against a concentration gradient. Mycorrhizal fungi (mycelium and sporocarps) only absorbed $\mathrm{Co}, \mathrm{Ni}$, and $\mathrm{Pb}$ but did not accumulate these elements in their thalli. Metal accumulation within fungal mycelium biomass in the top forest soil layer $(0-5 \mathrm{~cm})$ may account for about $5 \%$ of the total amount of $\mathrm{Co}, 4 \% \mathrm{Ni}, 7 \% \mathrm{Cu}, 8 \% \mathrm{Zn}, 24 \% \mathrm{Cd}$, and $3 \% \mathrm{~Pb}$.
\end{abstract}

\section{Introduction}

Ectomycorrhizal fungi are major components of fungal community in the soils of most boreal and temperate forests. The mycelium of soil fungi plays a crucial role in nutrient cycling and nutrient uptake into plants from soil via the formation of symbiotic mycorrhizal associations [1]. Mycorrhizal fungi increase the surface absorbing area of roots and enhance nutrient uptake into the host plant: this is due to the physical geometry of the mycelium and its ability to mobilise nutrients from organic substrates through the action of extracellular catabolic enzymes [2].

Mycorrhizal mycelia have the ability to take up mineral nutrients [3] and mycorrhizal fungi acquire both essential macronutrients, such as phosphorus [4], and are efficient at taking up and accumulating microelements [3]. This includes the accumulation of both nonessential elements and trace metals $[5,6]$, such as the heavy metal cadmium (Cd), an element of concern for food quality as its behaviour is analogous to essential metals, and essential nutrient elements such as zinc $(\mathrm{Zn})$ and the trace element copper $(\mathrm{Cu}) . \mathrm{Cd}, \mathrm{Zn}$, and $\mathrm{Cu}$ accumulate in mushroom thalli $[7,8]$. Sporocarps of many macrofungi might contain extremely high levels of heavy metals, with $\mathrm{Cd}$ being among the most intensively accumulated metal [9-13]. Relatively high $\mathrm{Cu}$ and $\mathrm{Zn}$ concentrations (bioaccumulation values higher than 1) in certain species of wild growing fungi are also reported $[8,11$, $12,14]$.

Thus, soil fungi, especially fungal sporocarps, are involved in the recycling heavy metals in forest ecosystems through bioaccumulation [10]. In addition, the mycelium of ectomycorrhizal fungi has the potential for taking up metallic elements from the soil and transporting them within the fruiting body [15], which can have important consequences for the retention, mobility, and availability of these elements in forest ecosystems.

However, the capacity for retaining metal among species of fungi is wide [16] and the capability of fungi to accumulate elements differs [17]. Essential nutrients, such as cobalt (Co) and nickel $(\mathrm{Ni})$, and nonessential lead $(\mathrm{Pb})$ appear to be excluded from fungi, as they do not accumulate $[18,19]$.

Fungal sporocarps comprise only a few percentage of the total mycelia biomass in a forest ecosystem [20]. This means that a majority of fungal biomass in soil is located within the 
upper soil horizons below the soil surface [21]. However, the ability of fungal mycelium to accumulate metal contents in mycelia is unclear and few studies are available $[18,22]$.

Although ectomycorrhizal fungi profoundly affect forest ecosystems through mediating nutrient uptake and maintaining forest food webs, the accumulation of metals at each transfer step from bulk soil to fungal sporocarps is unclear. The rhizosphere appears important for understanding the transfer of metals from soil to fungi. However, the fungi/soil concentration ratio for metals is not well studied under field conditions nor is much known about whether there is a difference between the uptake of metals from soil to fungi (mycelium/soil ratio) and transport within fungal thalli (sporocarps/mycelium ratio).

We attempted to quantify the uptake and distribution of $\mathrm{Co}, \mathrm{Ni}, \mathrm{Cu}, \mathrm{Zn}, \mathrm{Cd}$, and $\mathrm{Pb}$ in the soil-mycelium-sporocarps compartments in various transfer steps: bulk soil, rhizosphere, soil-root interface, fungal mycelium, and sporocarps.

\section{Materials and Methods}

2.1. Sampling Area. The study area was located near Forsmark, in a forest ecosystem on the east coast of central Sweden $\left(60^{\circ} 22^{\prime} \mathrm{N}, 18^{\circ} 13^{\prime} \mathrm{E}\right)$. The soil at the site is sandy or clay till. The field layer consists of bilberry (Vaccinium myrtillus L.), bracken (Pteridium aquilinum (L.) Kuhn.), coltsfoot (Tussilago farfara L.), horsetail (Equisetum silvaticum L.), and stone bramble (Rubus saxatilis L.). The tree layer comprises pure Norway spruce (Picea abies (L.) H. Karst.) or spruce mixed with Scots Pine (Pinus sylvestris L.), both about 100 years old. Further details about the site are presented by Lundin et al. [23]. Ten sampling plots (approx. $10 \mathrm{~m}^{2}$ each) were established $20-50 \mathrm{~m}$ apart within the ecosystem, in an area of approximately 2.0 ha. The dominant trees were spruce on plots $1-7$ and Scots Pine on plots $8-10$.

2.2. Sampling of Soil and Fungi. Samples of soil and fungal sporocarps were collected from 10 sampling plots during September to November 2003. Four replicate soil samples were collected around and directly underneath fungal sporocarps (from an area of about $0.5 \mathrm{~m}^{-2}$ ) within each $10-\mathrm{m}^{2}$ plot. After the removal of fresh leaves and litter, soil cores were taken to a depth of $10 \mathrm{~cm}$ with a cylindrical steel tube $5.7 \mathrm{~cm}$ in diameter. These soil cores were divided horizontally in situ into two $5 \mathrm{~cm}$ thick layers and stored in plastic bags at $4^{\circ} \mathrm{C}$ until analysis.

The sporocarps of 12 different fungal species were collected and cleaned of extraneous material: the species level was identified in the laboratory. The sporocarps were dried at $35^{\circ} \mathrm{C}$ to constant weight for determination of $\mathrm{Co}, \mathrm{Ni}, \mathrm{Cu}$, $\mathrm{Zn}, \mathrm{Cd}$, and $\mathrm{Pb}$ concentration. Portions of soil samples taken from $0-5$ and $5-10 \mathrm{~cm}$ depth were also used for chemical analyses. The majority of the prepared mycelia were assumed to belong to the same species, with some inclusion of other species, as whether mycelia extracted from the soil samples and sporocarps belonged to the same species was not determined.
2.3. Preparation of Fungal Mycelium and Fractionation of Soil. Soil portions (30-50 g) were used for extracting fungal mycelium. The fungal structures were isolated from the soil samples (0-5 cm layer) with forceps and under a dissection microscope (magnification $64 \mathrm{x}$ ), small amounts of distilled water were added to the sample to disperse the soil. The prepared fraction of mycelium contained aseptate and septate hyphae, strands and rhizomorphs, sclerotia, and a small number of mycorrhizal root tips. The method for mycelium preparation is described by [24]. Mycelium samples were dried at $35^{\circ} \mathrm{C}$ to constant weight for determination of $\mathrm{Co}, \mathrm{Ni}$, $\mathrm{Cu}, \mathrm{Zn}, \mathrm{Cd}$, and $\mathrm{Pb}$. The amount of mycelium obtained from each soil sample varied between 30 and $60 \mathrm{mg}$ dry weight (DW) per gram of soil.

The soil samples $(0-5 \mathrm{~cm}$ layer $)$ were partitioned according to the method described by [25]. Large roots, stones, and pieces of wood were removed, and the remaining soil was gently sieved through a $2 \mathrm{~mm}$ mesh. This sieved material was termed the bulk soil fraction. The soil aggregates containing roots that remained on the sieve were crumbled and gently squeezed between the fingers, resulting in the separation of more soil from the roots; this was termed the rhizosphere fraction. The residue, which was called the soil-root interface fraction, consisted of the finest roots with adhering soil particles. In the total, nine samples of bulk soil fraction and mycelium, 12 samples of fungal sporocarps (each sample represents one species), and 6 samples of rhizosphere and soil-root interface fraction were analysed for $\mathrm{Co}, \mathrm{Ni}, \mathrm{Cu}, \mathrm{Zn}$, $\mathrm{Cd}$, and $\mathrm{Pb}$ concentration.

2.4. Chemical Analyses and Radiometry. Soil organic matter content (OMC) was determined by heating a known mass of soil to $550^{\circ} \mathrm{C}$. Soil $\mathrm{pH}$ was determined in a $1: 5$ soil : water suspension ( $5 \mathrm{~g}$ of soil).

For element analyses, a $2.5 \mathrm{~g}$ portion of each sample was mixed with $5 \mathrm{~mL} \mathrm{HNO}_{3}+0.5 \mathrm{~mL} \mathrm{30 \%} \mathrm{hydrogen} \mathrm{peroxide.}$ The mixture was then digested in a microwave oven, diluted with MQ water (water that has been purified using an ion exchange cartridge), and analysed with an inductively coupled plasma technique. Alkali metals were analysed at the laboratories of ALS Scandinavia AB, Luleå, a company within the ALS Laboratory Group, and all analyses were accompanied by rigorous quality control measures. Accuracy was assessed with peach leaves NIST 1547 (NIST, Gaithenburg, Nebraska, USA), a plant certified reference material with a matrix sufficiently close to fine roots and fungal material. The recoveries were $102.4 \%$ for Co, $101.4 \%$ for $\mathrm{Ni}, 103.5 \%$ for $\mathrm{Cu}, 99.4 \%$ for $\mathrm{Zn}, 104.6 \%$ for $\mathrm{Cd}$, and $101.9 \%$ for $\mathrm{Pb}$. For soil, CRM SO ${ }^{-2}$ (heavy metals in soil) has been used, but has no certified values for $\mathrm{Co}, \mathrm{Ni}, \mathrm{Cu}, \mathrm{Zn}, \mathrm{Cd}$, or $\mathrm{Pb}$ : a detailed procedure of measurements is available in [26]. Bioconcentration ratios (BCR) were defined as the concentration of the element $\left(\mathrm{mg} \mathrm{kg}^{-1} \mathrm{DW}\right)$ in a specific fraction divided by the concentration of the element $\left(\mathrm{mg} \mathrm{kg}^{-1} \mathrm{DW}\right)$ in bulk soil for the $0-10 \mathrm{~cm}$ soil layer.

2.5. Statistical Analyses. Data were analysed by one-way analysis of variance. Relationships between $\mathrm{Co}, \mathrm{Ni}, \mathrm{Cu}, \mathrm{Zn}, \mathrm{Cd}$, 
TABle 1: Mean concentrations of $\mathrm{Co}, \mathrm{Ni}$ and $\mathrm{Cd}\left(\mathrm{mg} \mathrm{kg}^{-1} \mathrm{DW}\right)$ in soil fractions and fungi, mean values \pm standard deviation.

\begin{tabular}{|c|c|c|c|c|c|}
\hline Element & Bulk soil & Rhizosphere & Soil-root interface & Fungal mycelium & Fruit bodies \\
\hline Co & $0.79 \pm 0.44^{\mathrm{a}}$ & $1.06 \pm 0.6^{\mathrm{a}}$ & $0.59 \pm 0.29^{a}$ & $0.98 \pm 0.65^{\mathrm{a}}$ & $0.11 \pm 0.13$ \\
\hline $\mathrm{Ni}$ & $3.45 \pm 2.1^{\mathrm{a}}$ & $4.62 \pm 2.1^{\mathrm{a}}$ & $2.01 \pm 1.0^{\mathrm{a}}$ & $3.13 \pm 1.9^{\mathrm{a}}$ & $0.55 \pm 0.34$ \\
\hline $\mathrm{Cu}$ & $10.4 \pm 7.8^{\mathrm{a}}$ & $13.1 \pm 5.5^{\mathrm{a}}$ & $11.9 \pm 4.5^{\mathrm{a}}$ & $15.8 \pm 5.7^{\mathrm{a}}$ & $28.8 \pm 17.3$ \\
\hline $\mathrm{Zn}$ & $38.5 \pm 24.7^{\mathrm{a}}$ & $31.9 \pm 9.6^{\mathrm{a}}$ & $44.2 \pm 5.4^{\mathrm{a}}$ & $69.7 \pm 22.1^{\mathrm{b}}$ & $120.2 \pm 5.7$ \\
\hline $\mathrm{Cd}$ & $0.29 \pm 0.13^{\mathrm{a}}$ & $0.35 \pm 0.11^{\mathrm{a}}$ & $0.81 \pm 0.39^{b}$ & $1.5 \pm 1.6^{\mathrm{b}}$ & $3.1 \pm 3.1$ \\
\hline $\mathrm{Pb}$ & $18.4 \pm 8.6^{\mathrm{a}}$ & $16.5 \pm 6.2^{\mathrm{a}}$ & $7.7 \pm 2.4^{\mathrm{b}}$ & $12.6 \pm 4.7^{\mathrm{a}}$ & $0.25 \pm 0.17$ \\
\hline
\end{tabular}

The means within rows with different letters $(\mathrm{a}, \mathrm{b})$ represent a significant difference $(P<0.01)$.

and $\mathrm{Pb}$ concentrations in different soil fractions and fungi were determined with Pearson correlation coefficients and 2sample $t$-test. All statistical analyses were run with Minitab (2010 Minitab Inc.) software.

\section{Results}

3.1. Soil Characteristics. At the site, soil $\mathrm{pH}$ was high: in the $0-5 \mathrm{~cm}$ layer, the mean $\mathrm{pH}$ was 5.2 (range 3.8-6.9), and in the 5-10 $\mathrm{cm}$ layer, mean $\mathrm{pH}$ was 5.1 (range 3.6-7.1). For the entire $0-10 \mathrm{~cm}$ layer, the highest soil $\mathrm{pH}$ values $(6.5-6.9)$ were in plots 1,2 , and 5 : the $\mathrm{pH}$ values in the other plots were ranged from 3.7 to 5.1 .

Soil organic matter content (OMC) at the study site was also high. The mean $\mathrm{OMC}$ in the $0-5 \mathrm{~cm}$ layer was $66.2 \%$ (range 36.4-97.7), and in the 5-10 cm layer, the mean OMC was $52.9 \%$ (range $21.2-96.6$ ). For the $0-10 \mathrm{~cm}$ soil layer, the OMC values were high in plots $5(84.0 \%), 8(85.9 \%)$, and 9 (97.7\%). The $\mathrm{pH}$ and OMC values did not correlate to the uptake of the metals in either fungal sporocarps or mycelia, except for a moderate correlation between $\mathrm{pH}$ and $\mathrm{Cu}$ content in mycelium $(r=0.675, P=0.046)$ and sporocarps $(0.56 \mathrm{~ns})$, and a moderate correlation $(0.641 \mathrm{~ns})$ between $\mathrm{OMC}$ and $\mathrm{Pb}$ content in mycelium.

\subsection{Metal Concentrations in Soil and Fungal Compartments.} The concentration of $\mathrm{Co}, \mathrm{Ni}, \mathrm{Cu}$, and $\mathrm{Cd}$ in bulk soil was not significantly different from the concentration in the rhizosphere, although values for all metals were slightly higher in the rhizosphere fraction (Table 1).

Zinc and $\mathrm{Pb}$ concentrations were lower in the rhizosphere fraction than in bulk soil. The Cd concentration was higher and $\mathrm{Pb}$ concentration was lower in the soil-root interface fraction than in bulk soil: the concentration of $\mathrm{Co}, \mathrm{Ni}, \mathrm{Cu}$, and $\mathrm{Zn}$ was similar to in the bulk soil and rhizosphere fractions. In the fungal mycelium fractions, $\mathrm{Zn}$ and $\mathrm{Cd}$ concentrations were significantly $(P<0.01)$ higher than in the bulk soil and rhizosphere fractions. Fungal mycelium fraction was noticeably, although not statistically significant, concentrated with $\mathrm{Cu}$ : the concentration of lead in mycelium was lower than in the bulk soil and rhizosphere fractions.

The Cd concentration in the soil-root interface fraction was 4.0-fold higher than in bulk soil and 5.7-fold higher in mycelium than in bulk soil (Table 2). Zinc concentration was 2.2-fold higher in the soil-root interface fraction and 2.4fold higher in the mycelium than in bulk soil. Copper concentrations varied considerably among the samples but there were no significant differences among the different soil fractions analysed (Table 2). The bioconcentration ratio in sporocarps generally followed a similar pattern, but the enrichment of $\mathrm{Cd}, \mathrm{Zn}$, and $\mathrm{Cu}$ in the sporocarps was more obvious (Table 2).

Based on the bioconcentration ratios, fungal sporocarps accumulated larger amounts of $\mathrm{Cu}, \mathrm{Zn}$, and $\mathrm{Cd}$ than mycelium. For example, $\mathrm{Cu}$ concentrations in fungal sporocarps collected from the same plots, where soil samples and mycelium were extracted, were about 1.8 -fold higher than $\mathrm{Cu}$ concentrations found in mycelium. The concentrations of $\mathrm{Zn}$ in fungal sporocarps were about 1.4-fold higher than in the corresponding fungal mycelium and $\mathrm{Cd}$ was about 1.5 -fold higher (Tables 2 and 3 ).

The bioconcentration ratios for each element varied among the species of fungal sporocarps sampled (Table 3 ). In general, most analysed species, except Lactarius deterrimus and Cortinarius odorifer tended to accumulate $\mathrm{Cu}$. Most fungal species, except saprotrophic fungi Hypholoma capnoides and Collybia peronata, accumulated Zn. All fungal sporocarps, except Suillus granulatus, accumulated Cd. The bioconcentration ratio values for $\mathrm{Cd}$ were high: the BCR for Cortinarius armeniacus was above 30 . The concentration of $\mathrm{Co}, \mathrm{Ni}$, and $\mathrm{Pb}$ in sporocarps was lower than the concentration in bulk soil and mycelium. Among other species, Cortinarius armeniacus and Cortinarius sp. had the highest content of all metals studied (Table 3).

3.3. Relationships between Copper, Zinc, and Cadmium in Soil and Fungi. Although not significant, there was an obvious relationship between the concentration of $\mathrm{Co}$ and $\mathrm{Ni}$ in mycelium and concentration in soil from which mycelium was extracted (Figures 1(a) and 1(b)). Sporocarps and mycelium $\mathrm{Cu}$ concentrations did not depend on soil concentrations, but $\mathrm{Zn}$ concentrations correlated to soil concentrations in both sporocarps and mycelium (Figures $1(\mathrm{c})$ and $1(\mathrm{~d})$ ). There were no significant correlations between $\mathrm{Cd}$ in soil and Cd in mycelium or sporocarps (Figure 1(e)). Sporocarps concentration of $\mathrm{Co}$ and $\mathrm{Ni}$ and its soil concentration did not depend. There was a weak correlation in $\mathrm{Pb}$ concentration in both sporocarps and mycelium only (Figure 1(f)).

There were no significant correlations between the concentrations of the metals studied in fungi and soil $\mathrm{pH}$ or soil 
TABLE 2: Bioconcentration ratios (BCR: defined as concentration of the element $\left(\mathrm{mg} \mathrm{kg}^{-1} \mathrm{DW}\right)$ in the specific fraction divided by concentration of the element $\left(\mathrm{mg} \mathrm{kg}^{-1} \mathrm{DW}\right)$ in bulk soil), mean values \pm standard deviation.

\begin{tabular}{lcccc}
\hline Element & Rhizosphere & Soil-root interface & Fungal mycelium & Fruit bodies \\
\hline $\mathrm{Co}$ & $1.07 \pm 0.45$ & $0.62 \pm 0.29$ & $1.34 \pm 0.76$ & $0.22 \pm 0.34$ \\
$\mathrm{Ni}$ & $1.18 \pm 0.40$ & $0.49 \pm 0.14$ & $0.98 \pm 0.38$ & $0.21 \pm 0.14$ \\
$\mathrm{Cu}$ & $1.3 \pm 0.5$ & $1.2 \pm 0.6$ & $1.9 \pm 0.8$ & $3.4 \pm 2.2$ \\
$\mathrm{Zn}$ & $1.5 \pm 0.6$ & $2.2 \pm 0.9$ & $2.4 \pm 1.4$ & $3.3 \pm 2.1$ \\
$\mathrm{Cd}$ & $1.6 \pm 0.7$ & $4.0 \pm 2.8$ & $5.7 \pm 4.6$ & $8.8 \pm 9.2$ \\
$\mathrm{~Pb}$ & $1.18 \pm 0.50$ & $0.56 \pm 0.26$ & $0.87 \pm 0.60$ & $0.013 \pm 0.008$ \\
\hline
\end{tabular}

TABLE 3: Element bioconcentration ratios (BCR: $\mathrm{mg} \mathrm{kg}^{-1} \mathrm{DW}$ in fungi)/( $\mathrm{mg} \mathrm{kg}^{-1} \mathrm{DW}$ in bulk soil) for fungal sporocarps.

\begin{tabular}{|c|c|c|c|c|c|c|c|}
\hline Plot & Species & Co & $\mathrm{Ni}$ & $\mathrm{Cu}$ & $\mathrm{Zn}$ & $\mathrm{Cd}$ & $\mathrm{Pb}$ \\
\hline 1 & Lactarius deterrimus & 0.004 & 0.07 & 0.65 & 3.60 & 3.89 & 0.009 \\
\hline 2 & Suillus granulatus & 0.005 & 0.01 & 1.93 & 2.82 & 0.91 & 0.008 \\
\hline 3 & Lactarius scrobiculatus & 0.198 & 0.16 & 3.28 & 2.48 & 6.92 & 0.016 \\
\hline 4 & Boletus edulis & 0.013 & 0.28 & 1.22 & 1.55 & 3.37 & 0.004 \\
\hline 5 & Cortinarius odorifer & 0.034 & 0.05 & 0.42 & 3.85 & 7.19 & 0.016 \\
\hline $5-7$ & Sarcodon imbricatus & 0.237 & 0.21 & 2.09 & 8.37 & 9.87 & 0.019 \\
\hline 6 & Cantharellus tubaeformis & 0.048 & 0.12 & 4.39 & 2.23 & 1.09 & 0.011 \\
\hline 6 & Lactarius trivialis & 0.113 & 0.31 & 3.33 & 2.93 & 4.41 & 0.024 \\
\hline 7 & Cortinarius armeniacus & 0.795 & 0.48 & 3.98 & 3.60 & 33.23 & 0.013 \\
\hline 8 & Cortinarius sp. & 1.084 & 0.45 & 6.74 & 5.14 & 17.23 & 0.030 \\
\hline $8-10$ & Hypholoma capnoides ${ }^{\mathrm{a}}$ & 0.045 & 0.18 & 3.02 & 0.52 & 2.27 & 0.005 \\
\hline $8-10$ & Tricholoma equestre & 0.024 & 0.22 & 5.54 & 5.06 & 5.80 & 0.004 \\
\hline 10 & Collybia peronata ${ }^{\mathrm{a}}$ & 0.316 & 0.22 & 7.24 & 0.46 & 18.78 & 0.015 \\
\hline
\end{tabular}

${ }^{\text {aSaprophyte. }}$

organic matter content (data not shown), except for $\mathrm{Pb}$ in sporocarps and soil OMC $(r=0.641, P=0.046)$. Ni concentration in sporocarps negatively correlated with soil $\mathrm{pH}$ $(r=-0.600, \mathrm{~ns})$.

\section{Discussion}

There were considerable amounts of the metals studied in all analyzed species of fungi and significant differences in the capability of accumulating these elements. Mycorrhizal fungi accumulate copper extensively [8, 27], and in this study, copper concentration increased in the following order: bulk soil < soil-root interface < rhizosphere < fungal mycelium $<$ fungal sporocarps. However, statistically higher concentrations of copper were only found in fungal sporocarps, compared to bulk soil. Copper accumulation $(\mathrm{BCR}>1$ ) was found in a majority of the sporocarps species analysed. Although myce-lium had about 2-fold higher copper concentration, this was not significantly different from the concentration in bulk soil. Despite uncertainty in the calculated values of the metal content in mycelium and sporocarps, these findings were in an agreement with previous studies $[12,14]$, where concentration of $\mathrm{Cu}$ in fungal sporocarps is higher than in topsoil. Thus, the ability to accumulate copper is greater in mycor-rhizal fungi sporocarps than in mycelium. The values for the mean $\mathrm{Cu}$ concentration in mycelium were lower than the values reported for ectomycorrhiza $\left(337 \pm 140 \mu \mathrm{g} \mathrm{g}^{-1}\right.$ mycorrhiza) from the top organic layer of coniferous forest soils in Norway [18]: a plausible explanation might be that soils in Norway were contaminated with $\mathrm{Cu}$.

Zinc also concentrated in mushroom thalli. Zinc concentrations increased in the following order: bulk soil < soil-root interface $<$ fungal mycelium $<$ fungal sporocarps. However, there was a 2-fold (fungal mycelium) and 3-fold (sporocarps) higher concentration of $\mathrm{Zn}$ than in bulk soil. The data agreed with results from other studies [14, 27], although there is only limited data available for zinc concentration in mycelium extracted from the soil where sporocarps grow. According to Berthelsen et al. [18], the mean $\mathrm{Zn}$ concentration is $456 \pm 201 \mu \mathrm{g} \mathrm{g}^{-1}$ of mycorrhiza, which is much higher than values obtained in this study. One difference may be due to the study area, the study area of Berthelsen et al. [18] is located in a part of Norway exposed to considerable amounts of airborne deposition of heavy metals such as $\mathrm{Cd}$ and $\mathrm{Zn}$.

Cadmium concentrations increased in the following order: bulk soil $<$ rhizosphere $<$ soil-root interface $<$ fungal mycelium $<$ fungal sporocarps. Fungi appeared to have a high preference for $\mathrm{Cd}$, as the accumulation of $\mathrm{Cd}$ by fungi, both mycelium and especially fungal sporocarps, was pronounced, with a mean BCR of about $6: 1$ for mycelium and 9:1 for sporocarps. The accumulation of $\mathrm{Cd}$ by fungal sporocarps is apparently species dependent [8]. Extremely high levels of $\mathrm{Cd}$ are reported from fruiting bodies of some 


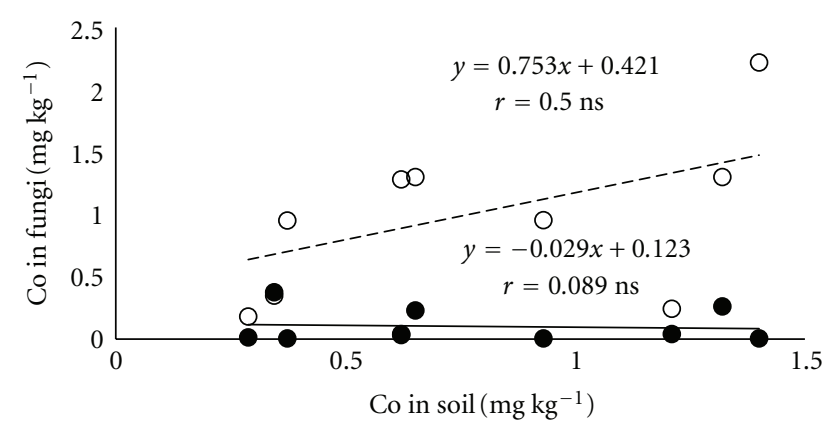

(a)

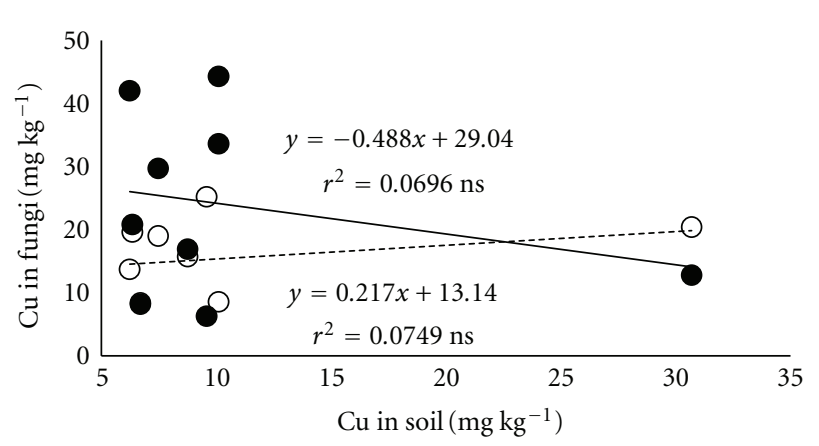

(c)

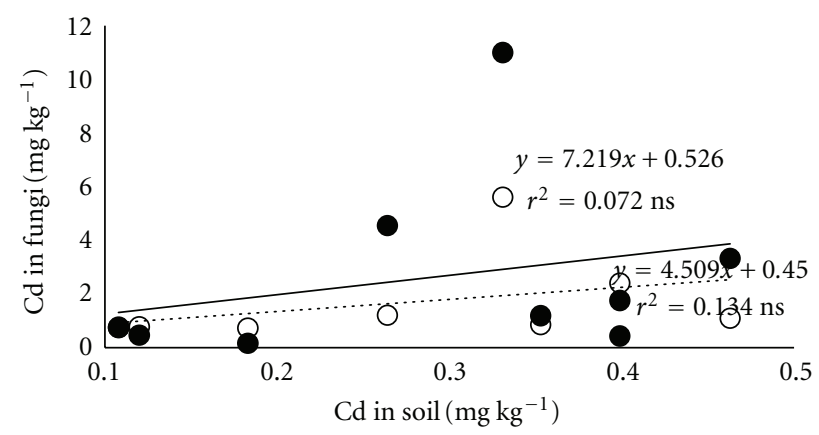

(e)

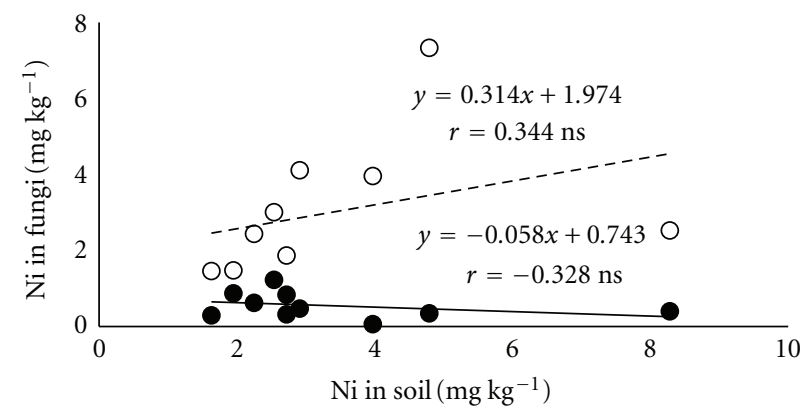

(b)

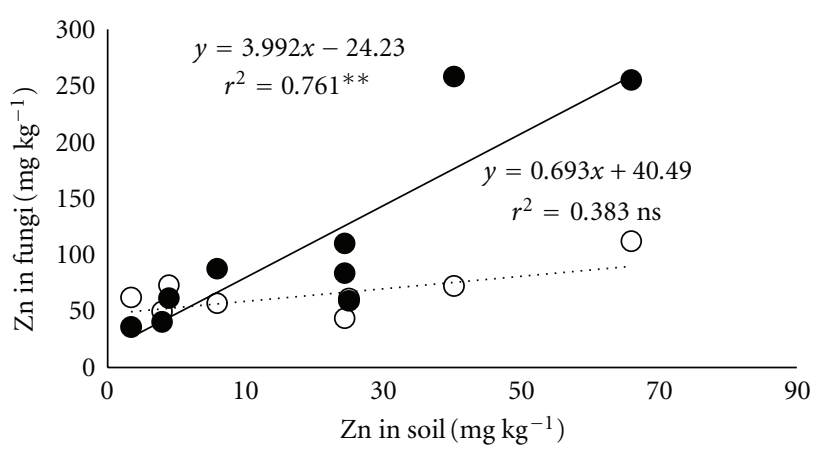

(d)

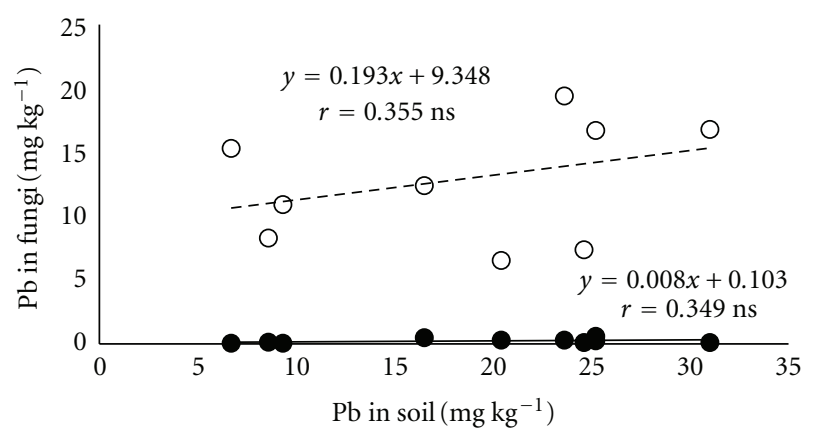

(f)

FIGURE 1: Relationships between concentration of $\mathrm{Co}(\mathrm{a}), \mathrm{Ni}(\mathrm{b}), \mathrm{Cu}(\mathrm{c}), \mathrm{Zn}(\mathrm{d}), \mathrm{Cd}(\mathrm{e})$, and $\mathrm{Pb}$ (f) in fungal sporocarps (filled circle, solid line) and soil mycelium (non-filled circle, dotted line) in relation to the soil in which they are growing. ${ }^{* *} P<0.01$.

of fungi, especially the toxic Amanita sp. [13, 28]. This could explain the species variation for both mycelium and sporocarps: the standard deviation values for $\mathrm{Cd}$ were as high as the mean values. However, both fungi and other fractions, for example, the rhizosphere and soil-root interface fractions, were noticeably enriched with $\mathrm{Cd}$, although this was only significant for the soil-root interface fraction.

The capability of fungal species for accumulating essential $(\mathrm{Co}, \mathrm{Ni})$ and nonessential $(\mathrm{Pb})$ metals differs $[16,17]$. The $\mathrm{Co}, \mathrm{Ni}$, and $\mathrm{Pb}$ concentrations were generally evenly distributed between soil fractions and mycelium, whereas the concentration of these metals in sporocarps was lower. Lead elimination from the sporocarps was more pronounced: the concentration in sporocarps was about 70 times lower than in bulk soil and about 50 times lower than in mycelium. Similarly, Campos et al. [17] observe only absorption of $\mathrm{Pb}$, but not accumulation, in the ectomycorrhizal fungus Cantharellus cibarius. The differences in metal concentrations between the mycelium and the sporocarps (assuming they belonged to the same species) indicate that there is no further transport of $\mathrm{Co}, \mathrm{Ni}$, and $\mathrm{Pb}$ within sporocarps after being taken up by mycelium from soil, that is, active transport from mycelium to sporocarps for those metals is absent. Apart of this, $\mathrm{Cd}, \mathrm{Cu}$, and $\mathrm{Zn}$ are soluble elements, while $\mathrm{Co}, \mathrm{Ni}$, and $\mathrm{Pb}$ are much less soluble. $\mathrm{Pb}$ in organic soils is more strongly bound to soil, whereas, for example, $\mathrm{Cd}$ is only weakly bound [29]. These findings indicated that fungi (both mycelium and sporocarps) accumulate $\mathrm{Cd}$ to $\mathrm{Zn}$ and $\mathrm{Cu}$, and $\mathrm{Co}, \mathrm{Ni}$, and $\mathrm{Pb}$ were excluded from the sporocarps and not accumulated. Based on the BCR values for fungal sporocarps and mycelium (Table 2), the accumulation of the metals could be ranked in the following order: $\mathrm{Cd}^{2+}>\mathrm{Zn}^{2+}>\mathrm{Cu}^{2+}$, 
with a relative ratio of $100: 41: 38$. In terms of the amount of metals accumulated per mass unit by both mycelium and sporocarps, the metals could be ranked in decreasing order: $\mathrm{Zn}^{2+}>\mathrm{Cu}^{2+}>\mathrm{Pb}^{2+}>\mathrm{Cd}^{2+}>\mathrm{Ni}^{2+}>\mathrm{Co}^{2+}$, with a relative ratio of $180: 45: 13: 5: 4: 1$.

The analyse of relationships between the concentrations of the metals in soil, mycelia, and fungal sporocarps indicated only essential $\mathrm{Zn}$ concentration in soil correlated with the concentration in sporocarps, and to certain degree in mycelium. The concentrations of $\mathrm{Cu}$ and $\mathrm{Cd}$ in fungi did not correlate with the concentrations in soil, whereas mycelium concentration of $\mathrm{Co}, \mathrm{Ni}$, and $\mathrm{Pb}$ was only weakly or moderately (not significantly) related to soil concentration. The extent of metal transfer from soil to fungi is apparently species-specific and influenced by both the bioavailability of the metals and the age of the mushroom [22]. The variation in metal contents between edible mushrooms species also depends on the ability of the species to extract elements from the substrate [30] and competitive interaction between metals affects nutrient uptake capacities of the fungi [31].

The estimated values for soil mycelium biomass ranged from 30 to $60 \mathrm{mg}$ DW of mycelium per one gram DW of soil (0-5 cm layer). Assuming a dry bulk density with $0.4 \mathrm{~g} \mathrm{~cm}^{-3}$ in the upper layers of soil in the Forsmark area [23], fungal mycelium was an important constituent of the organic surface soil and comprised between 3 and $6 \%$ by volume in the upper $5 \mathrm{~cm}$ of the forest soil. Based on the metal concentration in the bulk soil fraction and mycelium extracted from the same soil, fungal mycelium might accumulate appreciable amounts of the soil metals. The amount of Cd accumulated in fungal structures accounted for 15.5-31.7\% of the total amount of $\mathrm{Cd}$ in soil. The fungal content of $\mathrm{Zn}$ in the top soil layer accounted for 5.4 and $10.9 \%$ of the total and fungal mycelium comprised between 4.6 and $9.1 \%$ of the total $\mathrm{Cu}$ content in soil. In fungal mycelium, the accumulation of Co was 3.5-6.9\%, Ni was $2.6-5.2 \%$, and $\mathrm{Pb}$ was 2.0-3.9\%. The estimation of fungal biomass in soil may be relevant, as Berthelsen et al. [18] report similar data for fungal biomass in a Norwegian forest soil. Although the fungal contents of $\mathrm{Cu}, \mathrm{Zn}$, and $\mathrm{Cd}$ presented here were lower than reported by Berthelsen et al. [18], the discrepancy may be due to the difference in concentration level of metals in soil. The area in Norway has been exposed to airborne deposition of heavy metals, which can explain the higher accumulation by mycelium of fungi. Another source of discrepancy is the difference in methods used for mycelium estimation. Here a direct method was used, which meant mycelium biomass might have been underestimated rather than overestimated, whereas the ergosterol method used in Norway [18] may lead to overestimated mycorrhizal fungal biomass values. The fungal content of $\mathrm{Pb}(2-4 \%)$ supported previous reports of $<3 \%$ of the soil $\mathrm{Pb}$ content [18].

\section{Conclusions}

The concentration of $\mathrm{Cu}, \mathrm{Zn}$, and $\mathrm{Cd}$ in mycelium was about 2-5 times higher than in bulk soil and the concentrations in sporocarps were about 1.5-2 times higher than in mycelium.
The concentration of $\mathrm{Co}$ and $\mathrm{Ni}$ in mycelium was similar to the concentrations in other soil fractions (bulk soil, rhizosphere, soil-root interface); whereas, the concentrations in sporocarps were about 5-9 times lower than in mycelium. The concentration of $\mathrm{Pb}$ in mycelium was about 1.5 times lower than in other soil fractions (bulk soil, rhizosphere, soilroot interface) and about 50 times lower than in mycelium. The uptake of $\mathrm{Cu}, \mathrm{Zn}$, and $\mathrm{Cd}$ during the entire transfer process between soil and sporocarps occurs against a concentration gradient. The mycorrhizal fungi (mycelium and sporocarps) only absorbed cobalt, nickel, and lead but did not accumulate these metals in thalli.

\section{Acknowledgments}

The author would like to thank Professor K. Johanson, Drs. I. Nikolova and A. Taylor for their assistance with experiments and to the staff of the Analytica Laboratory, Luleå, for ICPAES and ICP-SFMS analyses. The project was financially supported by SKB (Swedish Nuclear Fuel) and Waste Management Co.

\section{References}

[1] D. J. Read and J. Perez-Moreno, "Mycorrhizas and nutrient cycling in ecosystems - a journey towards relevance?" New Phytologist, vol. 157, no. 3, pp. 475-492, 2003.

[2] J. R. Leake and D. J. Read, "Mycorrhizal fungi in terrestrial habitats," in The Mycota IV: Environmental and Microbial Relationship, D. T. Wicklow and B. Söderström, Eds., pp. 281301, Springer, Berlin, Germany, 1997.

[3] S. E. Smith and D. J. Read, Mycorrhizal Symbiosis, Academic Press, London, UK, 2nd edition, 1997.

[4] T. I. Burgess, N. Malajczuk, and T. S. Grove, "The ability of 16 ectomycorrhizal fungi to increase growth and phosphorus uptake of Eucalyptus globulus Labill. and E. diversicolor F. Muell.," Plant and Soil, vol. 153, no. 2, pp. 155-164, 1993.

[5] T. Stijve and R. Besson, "Mercury, cadmium, lead and selenium content of mushroom species belonging to the genus Agaricus," Chemosphere, vol. 5, no. 2, pp. 151-158, 1976.

[6] J. Vetter, I. Siller, and Z. Horváth, "Zinc content of sporocarps of basidiomycetous fungi," Mycologia, vol. 89, no. 3, pp. 481483, 1997.

[7] D. Blaudez, B. Botton, and M. Chalot, "Cadmium uptake and subcellular compartmentation in the ectomycorrhizal fungus Paxillus involutus," Microbiology, vol. 146, no. 5, pp. 11091117, 2000.

[8] M. Blanuša, A. Kučak, V. M. Varnai, and M. M. Sarić, "Uptake of cadmium, copper, iron, manganese, and zinc in mushrooms (Boletaceae) from Croatian forest soil," Journal of AOAC International, vol. 84, no. 6, pp. 1964-1971, 2001.

[9] A. R. Byrne, V. Ravnik, and L. Kosta, "Trace element concentrations in higher fungi," Science of the Total Environment, vol. 6, no. 1, pp. 65-78, 1976.

[10] N. W. Lepp, S. C. S. Harrison, and B. G. Morrell, "A role for Amanita muscaria L. in the circulation of cadmium and vanadium in a non-polluted woodland," Environmental Geochemistry and Health, vol. 9, no. 3-4, pp. 61-64, 1987.

[11] L. Svoboda, K. Zimmermannová, and P. Kalač, "Concentrations of mercury, cadmium, lead and copper in fruiting bodies 
of edible mushrooms in an emission area of a copper smelter and a mercury smelter," Science of the Total Environment, vol. 246, no. 1, pp. 61-67, 2000.

[12] C. Collin-Hansen, K. E. Yttri, R. A. Andersen, B. O. Berthelsen, and E. Steinnes, "Mushrooms from two metal-contaminated areas in Norway: occurrence of metals and metallothioneinlike proteins," Geochemistry: Exploration, Environment, Analysis, vol. 2, no. 2, pp. 121-130, 2002.

[13] M. Rudawska and T. Leski, "Trace elements in fruiting bodies of ectomycorrhizal fungi growing in Scots pine (Pinus sylvestris L.) stands in Poland," Science of the Total Environment, vol. 339, no. 1-3, pp. 103-115, 2005.

[14] C. C. Elekes, G. Busuioc, and G. Ionita, "The bioaccumulation of some heavy metals in the fruiting body of wild growing mushrooms," Notulae Botanicae Horti Agrobotanici ClujNapoca, vol. 38, no. 2, pp. 147-151, 2010.

[15] A. Brzostowski, G. Jarzyńska, A. K. Kojta, D. Wydmańska, and J. Falandysz, "Variations in metal levels accumulated in Poison Pax (Paxillus involutus) mushroom collected at one site over four years," Journal of Environmental Science and Health A, vol. 46, no. 6, pp. 581-588, 2011.

[16] A. A. Pérez, S. S. Farías, A. M. Strobl et al., "Levels of essential and toxic elements in Porphyra columbina and Ulva sp. from San Jorge Gulf, Patagonia Argentina," Science of the Total Environment, vol. 376, no. 1-3, pp. 51-59, 2007.

[17] J. A. Campos, N. A. Tejera, and C. J. Sánchez, "Substrate role in the accumulation of heavy metals in sporocarps of wild fungi," BioMetals, vol. 22, no. 5, pp. 835-841, 2009.

[18] B. O. Berthelsen, R. A. Olsen, and E. Steinnes, "Ectomycorrhizal heavy metal accumulation as a contributing factor to heavy metal levels in organic surface soils," Science of the Total Environment, vol. 170, no. 1-2, pp. 141-149, 1995.

[19] Z. R. Holan and B. Volesky, "Accumulation of cadmium, lead, and nickel by fungal and wood biosorbents," Applied Biochemistry and Biotechnology, vol. 53, no. 2, pp. 133-146, 1995.

[20] T. R. Horton and T. D. Bruns, "The molecular revolution in ectomycorrhizal ecology: peeking into the black-box," Molecular Ecology, vol. 10, no. 8, pp. 1855-1871, 2001.

[21] E. Bååth, "Soil fungal biomass after clear-cutting of a pine forest in central sweden," Soil Biology and Biochemistry, vol. 12, no. 5, pp. 495-500, 1980.

[22] U. Thomet, E. Vogel, and U. Krähenbühl, "The uptake of cadmium and zinc by mycelia and their accumulation in mycelia and fruiting bodies of edible mushrooms," European Food Research and Technology, vol. 209, no. 5, pp. 317-324, 1999.

[23] L. Lundin, E. Lode, J. Stendahl, P. A. Merklund, L. Björkvald, and A. Thorstensson, "Soils and site types in the Forsmark area," SKB-Rapport R-04-08, Sv. Kärnbränslehantering, 2004.

[24] M. M. Vinichuk and K. J. Johanson, "Accumulation of ${ }^{137} \mathrm{Cs}$ by fungal mycelium in forest ecosystems of Ukraine," Journal of Environmental Radioactivity, vol. 64, no. 1, pp. 27-43, 2002.

[25] G. R. Gobran and S. Clegg, "A conceptual model for nutrient availability in the mineral soil-root system," Canadian Journal of Soil Science, vol. 76, no. 2, pp. 125-131, 1996.

[26] I. Rodushkin, E. Engström, D. Sörlin, and D. Baxter, "Levels of inorganic constituents in raw nuts and seeds on the Swedish market," Science of the Total Environment, vol. 392, no. 2-3, pp. 290-304, 2008.

[27] J. Alonso, M. A. García, M. Pérez-López, and M. J. Melgar, "The concentrations and bioconcentration factors of copper and zinc in edible mushrooms," Archives of Environmental Contamination and Toxicology, vol. 44, no. 2, pp. 180-188, 2003.
[28] P. Kalac, J. Burda, and I. Staskova, "Concentrations of lead, cadmium, mercury and copper in mushrooms in the vicinity of a lead smelter," Science of the Total Environment, vol. 105, pp. 109-119, 1991.

[29] P. Villaverde, D. Gondar, J. Antelo, R. López, S. Fiol, and F. Arce, "Influence of $\mathrm{pH}$ on copper, lead and cadmium binding by an ombrotrophic peat," European Journal of Soil Science, vol. 60, no. 3, pp. 377-385, 2009.

[30] C. Radulescu, C. Stihi, V. G. Cimpoca, I. V. Popescu, G. Busuioc, and A. I. Gheboianu, "Evaluation of heavy metals content in edible mushrooms by microwave digestion and Flame Atomic Absorption Spectrometry," Scientific Study and Research, vol. 12, no. 2, pp. 155-164, 2011.

[31] E. Krznaric, J. Wevers, and J. Colpaert, "Heavy metal tolerant fungi play a key role in the protection of pines against combined Zn-Cd toxicity," in Proceedings of the 21st New Phytologist Symposium, The Ecology of Ectomycorrhizal Fungi, Montpellier, France, December 2008, http://www.newphytologist .org/mycorrhizal/21stNPS.pdf. 

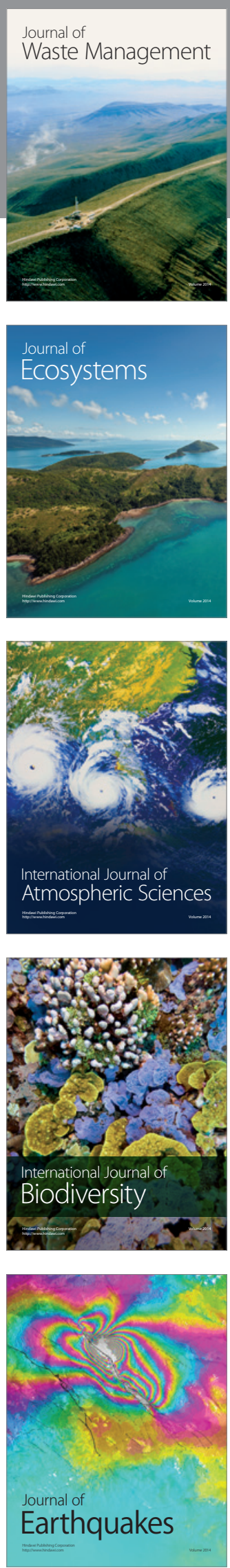
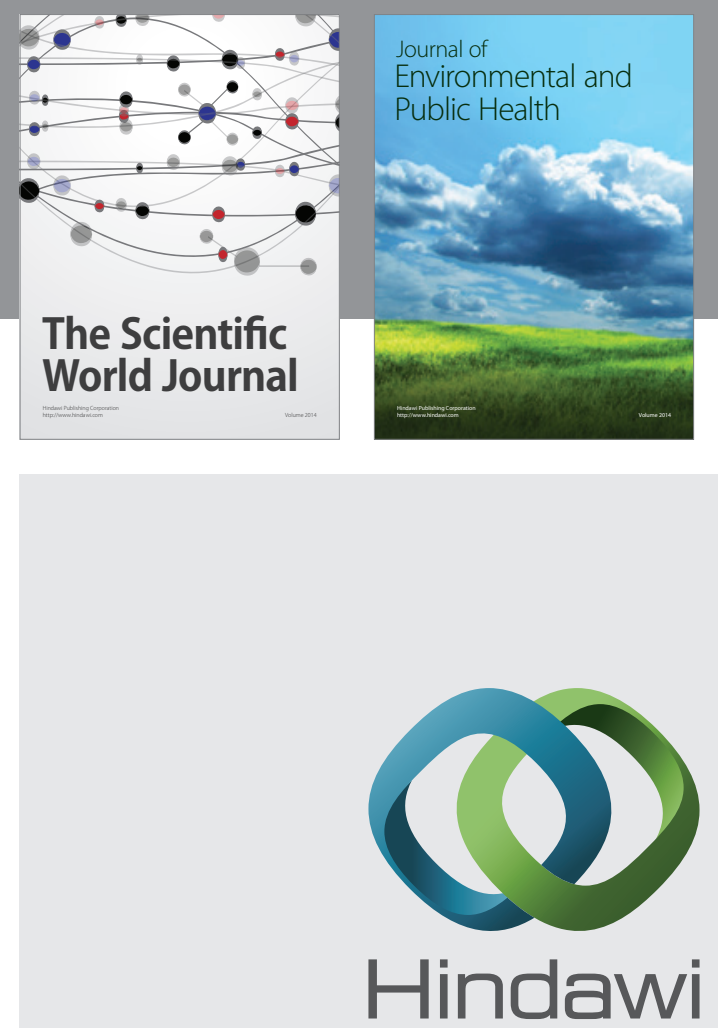

Submit your manuscripts at

http://www.hindawi.com
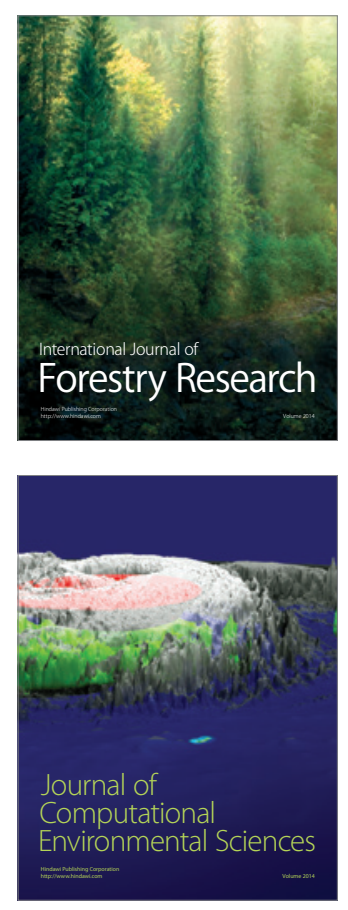
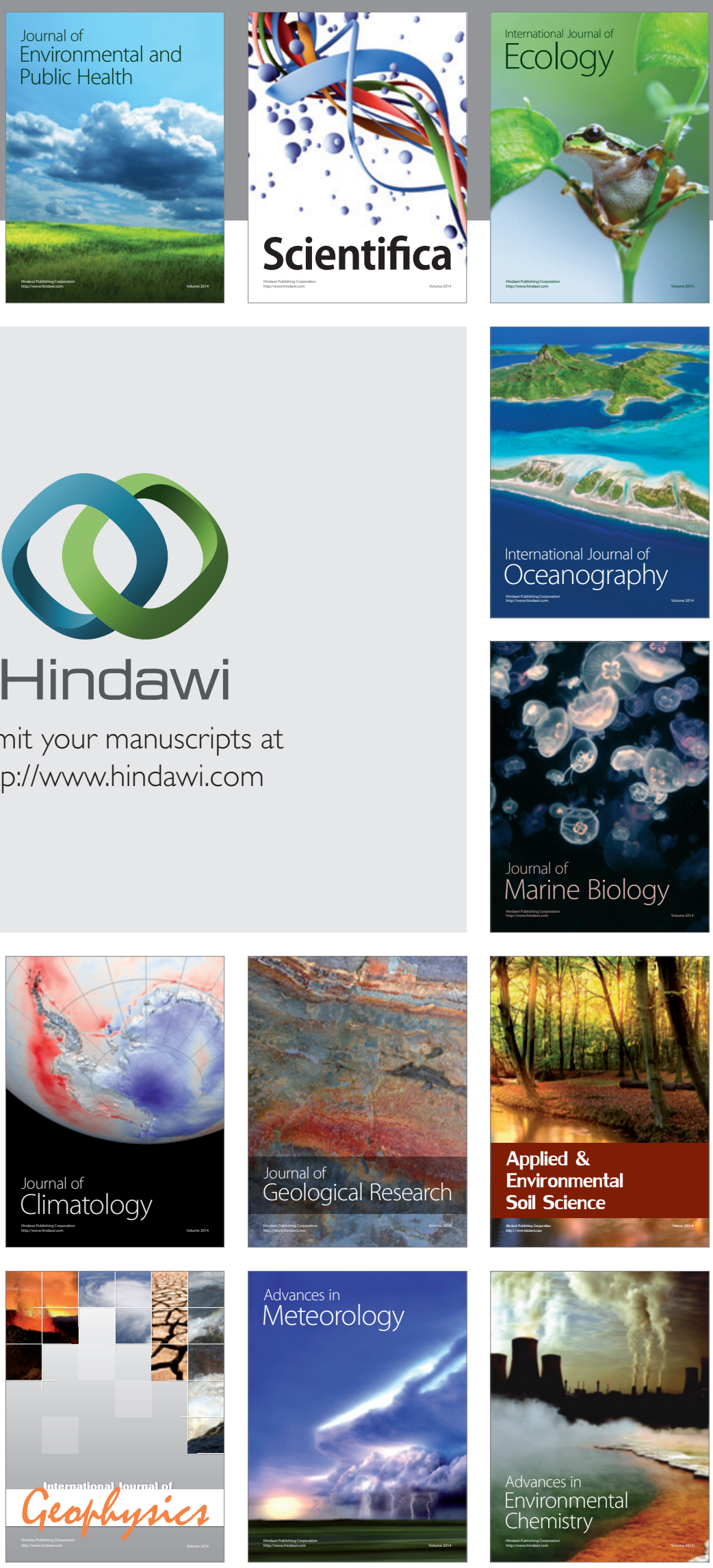